\title{
Kazakhstan in China's Belt and Road Initiative: An Empirical Analysis of Extensive and Intensive Margins of Trade
}

\author{
Dechun Huang, Mariya Yenina, Md. Ekram Hossain \\ Innovative Team of Philosophy and Social Sciences in Jiangsu Province, Higher Learning Institution, Business School, Hohai \\ University, Nanjing, China \\ Email: huangdechun@hhu.edu.cn,d2018014@hhu.edu.cn, mdekram_hossain@hhu.edu.cn
}

How to cite this paper: Huang, D. C., Yenina, M., \& Hossain, Md. E. (2021). Kazakhstan in China's Belt and Road Initiative: An Empirical Analysis of Extensive and Intensive Margins of Trade. Chinese Studies, 10, 1-16.

https://doi.org/10.4236/chnstd.2021.101001

Received: October 28, 2020

Accepted: December 13, 2020

Published: December 16, 2020

Copyright ( 2021 by author(s) and Scientific Research Publishing Inc. This work is licensed under the Creative Commons Attribution International License (CC BY 4.0).

http://creativecommons.org/licenses/by/4.0/

(c) (i) Open Access

\begin{abstract}
An important development of the One Belt One Road Initiative (OBOR) is to promote qualitative improvements in trade and trade regulation among participating countries. This paper provides an analysis of bilateral trade between China and Kazakhstan, covering a period of time from 2002 to 2017 and divided into major trade categories. The main purpose of this work is to review the bilateral relations between Kazakhstan and China and determine the development of trade at the initial stage of the OBOR project. To solve this problem, two analyses were chosen and, the results of this analysis may show an increase in trade turnover in those product categories that were previously stated in the project. Firstly, in order to investigate the gap of intensity, and extensity bilateral trade positions used the Hummels-Klenow indices for export margins of trade. Secondary to assess the relationship at the intra-industry level used analysis of the intra-industry trade (IIT) activities developed by Grubel and Lloyd. The empirical analysis of the IIT index is represented as partially balanced. China's performance was analyzed as intensive in the main elected categories such as the increase in the export intensity of trade in large volumes in product categories. The development of the project is confirmed by a numerical increase in interest in the categories stated in the project earlier.
\end{abstract}

\section{Keywords}

One Belt One Road Initiative, Trade Margins, Intra-Industry Trade Index, China-Kazakhstan Cooperation

\section{Introduction}

Different political, social changes and a fast-developing economy push forward 
countries to make trade relationships clear and profitable. There is a steady need for increasing the efficiency of trade relations. In recent years, there has been an enhancement interest in the project One Belt One Road (OBOR). OBOR was presented by the Chinese state to improve trade ties and establish long-term political and economic relations. It is concentrated to connect the Asian, European, and African regions. This project is represented by real and planned agreements. The cooperation under this project resonates in Kazakhstan's scientific literature as having a positive impact on the overall cost of foreign trade between China and the participating countries. There is a possibility of new trade relations between the countries under consideration (JSC Samruk-Kazyna, 2017). Authors believe that the development of OBOR between the countries of participants will help the qualitative improvement of trade and probably trade regulation (OECD, 2018). To date, authors are given the opportunity to consider the trade relations between China and Kazakhstan under the project OBOR. Since the beginning of the appearance, OBOR has passed comparatively not a big break, which can give a comparison of the change of trade between countries. So this work basis on the preceding years that give the possibility of the initial analysis of the effectiveness of OBOR and the trade flows.

The development of this topic mentions previous works of Kazakhstan and Chinese researchers. Allayarov \& Li (2017) been analyzed trade before 2014, in order of investigation it shows stable growth of bilateral trade, but not balanced, China had a more stable position in growing export. Paper applied trade indexes, such as the Grubel-Lloyd index and trade intensity index. Also in the work of the scientists (Zhang et al., 2017) reflected, the study of trade potential of Kazakhstan with China. The comparative advantage of the examined countries is very strong. On the other hand, bilateral trade complementary holds difficulties of intra-industry (IIT) surplus and deficiency. The findings are important for improving the trade policy of the countries.

The main indicators are estimated based on intra-industry trade and export margins of trade. One of the main assertions by Pak (2018), intra-industry trade helps to conclude successful integration in different countries' projects is the statement about integrating countries in different international projects and the main peculiarities of their specialization. In the profits remain countries specialize in the export and import of the same industries, if all the same countries partners specialize in cross-sector industries exchange, the links are not durable and in constant change. Until recently imperialist studies were based on the examination of distance coefficient affect transportation costs, in our time the emphasis is aimed at reviewing the effects of distance on the extensive and intensive margins of trade. The following theory is the basis of the beliefs about the trade relations of the countries being viewed. The consideration of this issue is based on the theory (Giri, 2007; Heckscher \& Ohlin, 1933), main provisions: there is a tendency to export those goods for the manufacture of which are used available in the country in excess of factors of production, other vises, to import goods for the production of which relatively rare factors are necessary. Also, this theory is 
applicable to empirical analysis between developed and developing countries. Describes (Helpman, Melitz, \& Rubinstein, 2008) dynamic industry model, introducing heterogeneity of products in the framework of the model of material competition. So, decided to consider the balance of trade of Kazakhstan with China and vice versa, as well as the search for the emergence of change in trade rotation.

The main aim of this work is to consider the bilateral relations between $\mathrm{Ka}$ zakhstan and China and to determine the development of trade turnover at the initial stage of the OBOR project. To solve this problem, two analyses were chosen and, in turn, it is assumed that the results of this analysis can be unfavorable in different categories. In this case, there are additional objectives of the empirical study such as the consideration of the main trading categories of goods and their synchronization with the main directions of trade currently under the OBOR project. The objective of the paper is to examine the current trade patterns of bilateral trade of China with Kazakhstan during the period 2002-2017, under OBOR initiative by focusing on intra-industry trade and export margins of trade and decided to consider the data in the full period and in different periods to identify the potential development of the OBOR project in the selected categories.

\section{Literature Review}

\subsection{A Brief Review of Kazakhstan in China's Belt and Road Initiative}

China's project One Belt One Road, one of the global modern initiatives, influence the development of the relationship between the countries of the region. One of the directions of the project lies from China through Kazakhstan and Russia to the Baltic Sea. Another direction also passes through Kazakhstan but leads already to the Mediterranean Sea, which is one of the hubs of world trade. Kazakhstan's geographical advantage in the new Silk Road project is considerable.

Visiting Kazakhstan in autumn 2013, President Xi Jinping put forward the idea of joint construction of the economic belt of the Silk Road. Later in Indonesia, he announced the idea of joint construction of the Sea Silk Road XXI century. Together they formed the initiative One Belt and One Road. The project will cover many spheres of state development. Such as infrastructure construction, investment in industrial capacity, development of natural resources, economic, financial cooperation, humanitarian exchanges, and environmental protection. The new conditions will create opportunities for integration of the transport system into the logistic network of the Eurasian region, as well as entering the growing markets of other countries. In order of this condition take part one of the important directions is trade development.

Economic and social relations between Kazakhstan and China have evolved over the long years. The attitude developed dynamically and productively, the economic geographical position of the country played a big role as well as a 
strong relationship in cooperation at different levels of production. The last few years have been allocated an increase in investment in the Kazakhstani economy. Assumes favorable time for the country and the possibility of accelerating development. The basic conditions created by Kazakhstan for investments and trade are the quantity of the rich fossil, stable and growing economy, and also protection of rights of investors. The country has prepared a successful platform for advancement long-term integration projects and strengthening the connection of the economic zone.

At the same time, countries began to develop projects on the integration of government infrastructure and the economic trading system. It became known on May 22, in Astana at the 25th plenary meeting of the Council of Foreign Investors under the President of Kazakhstan. The development of Kazakhstan as international trade, logistic, business, and financial hub was considered. As president (Nazarbayev, 2012) announced about the "New Silk Road project": "Kazakhstan should revive its historical role and become the largest business and transit hub of the Central Asian region, a peculiar bridge between Europe and Asia". That led to the beginning of the mechanism of investment and trade development in the country's economy and the formation of the funds.

On May 7th, 2013, Chinese President Xi Jinping voiced a global project "One Belt One Road Initiative" and confirmed long-term development in the direction with the intersecting project a new Silk Road. That entailed the development of various strategic models. The main concept of the project is the close cooperation and development in all main areas, Chinese President clearly outlined it. These five binding elements are policy coordination, facilities connectivity (interconnection infrastructures), trade facilitation, financial integration, and strengthening the relationship between peoples (people-to-people exchange). Certainly, all these areas will evolve and maintain relations with other countries. Chinese companies are actively implemented by major investment projects. China Kazakhstan cooperation was launched with a total investment of \$53.5 million. By (Xu, 2015) Kazakh-Chinese cooperation included 51 projects totaling worth $\$ 27$ billion. The number of Kazakhstan-Chinese enterprises also increasing. In Kazakhstan 422 joint companies, the year-ago number of enterprises company reached 353 . The growth rate is $19.5 \%$.

\subsection{Overview of Bilateral Trade Relation between Kazakhstan and China}

OBOR is a major inter-regional project, provides an analysis of the project, and describes the importance of building new partnerships and increasing the former. Further development of bilateral relations helps stable growth of trade relations. Further development and major problems for Kazakhstan in the project OBOR describes by (Satke \& Galdini, 2015). The long-forecast for the development of Kazakhstan as a connecting hub between East and West is also exhibited. The interconnected issue of contribution to export growth is the export of old goods to old markets. The above problem allows finding one of the weak 
points of trade policy and the need for diversification products and partners. Description of the increase in trade after the financial crisis is found in the literature (Simone, 2015; Sun, 2012). The increase in trade turnover at that time was not balanced, but China was able to strengthen its position in trade relations with Kazakhstan and occupied a leading position as a trading partner of Kazakhstan. In research (Li \& Edmonds, 2010) of Chinese trade with available countries was applied trade intensity index. China export and import to the Middle East had a higher position and improving its volume, in the gravity model import bias appears stronger.

Many researchers, when considering intra-industry trade, resort to analysis (Grubel \& Lloyd, 1975) in the intra-industry index. The work (Widodo, 2009) examined the intra-industry trade of the East Asian countries (including China) at different periods of time till the year 2006. East Asia region countries had growth in the development of the trade relations, but mainly in the intra-regional trade than in the inter-regional trade. In the work (Kim \& Meng, 2015) China's significant period of raising the intra-industry trade is revealed. The period of time 1987-2011 year showed great changes in the quality of China's exported goods. In the sphere of Kazakhstan trade, research of this issue is reflected in the analysis of intra-industry trade of CIS countries. In a comparison of the CIS countries, it was revealed that the manufactures countries have much higher intra-industry levels than others (Shelburne \& Pidufina, 2006).

The intensity of trade index applied by (Kojima, 1964) describing indicators for mutual trade compared to the volume of their part in world trade. Results of this study suggest trade can be more intensive if low resistance to trade is taken place between countries. These indexes found a place in modern literature (Allayarov \& Li, 2017). Investigation results of applying the above indexes to the bilateral relationship between China and Kazakhstan identified that during the period 1995-2014 years' export intensity decreased but import intensity increase. Conclude that Kazakhstan had a weaker position against China in trade relations.

The analysis of trade relations is also pursued in the literature (Dodonov, 2010) analysis led to the conclusion about the main categories of trade, China is planned for the energy sector of Kazakhstan, as well as the volume of trade in the middle of its development.

Basically, scientific theories about intensive and extensive margins are considered with two different perception prisms. The first researchers rely on the study of trade at the level of goods and conduct a decomposition of export growth (Amurgo-pacheco \& Pierola, 2008; Helpman, Melitz, \& Rubinstein, 2008; Prusa \& Besedes, 2011). The second introduces firm data and find statistical differences in the volume of countries' exports (Coughlin, 2012; Crozet \& Koenig, 2010; Hummels \& Klenow, 2005). In this research, the analysis of intensive and extensive margin will be used, based on the study (Hummels \& Klenow, 2005). Researches used trade margins to clarify the regularity, large economies trade more than countries with small economies. The counterbalance is chosen or it pro- 
motes the increase of spectra of the goods that is extensive margin, or at the expense of increased trade flow that is the intensive margin. Complementing this question to the basic theories of international trade (Evenett \& Venables, 2002) have considered that in statistics of bilateral trade dominate basically zero values. Reflecting the zero values to the expansion of the trade relations sector is worth; noticing in the work (Haveman \& Hummels, 2004) described the gradual, timely reduction of zero values, which means expanding the sector of trade relations. The results of empirical analysis (Kehoe \& Ruhl, 2013) reflected the importance of export costs in the development of export growth.

The volume of trade between China and Kazakhstan tended to grow during the whole bilateral relationship period. Especially intensively began to develop since the 1999 year and had a second big leap in the growth of trade relations in the 2010 year. Thus, for the period between 2008-2009 years and 2013 year, bilateral trade turnover decreased, but while a period of 1999-2003 years increased in 5 times. During 2010-2011 years showed the gap between import and export volume. Export of primary and mineral categories had $85 \%$ of the total export, but import had a great number of categories (Sun, 2012). That shows unstable and not balanced but increasing trade relationship. In the last five years, the project is actively developing OBOR initiative that brings the potential for the development of cooperation in the economic sphere. Consistent active growth of trade in 2015 and 2017 years, the foreign trade turnover between Kazakhstan and China on the results of 2016 amounted to 7.9 billion US\$ which is $25.4 \%$ below the 2015 year. Exports from Kazakhstan to China decreased by $23.1 \%$, amounting to 4.2 billion US\$ (by reducing the supply of oil, uranium, zinc, petroleum products, etc.). Import to Kazakhstan from China amounted to 3.7 US\$ Thousand, which is $28 \%$ lower than the results of the 2015 year It is noteworthy that Kazakhstan exported to China by $\$ 1.1$ billion more than imported. Thus, in the 2017 year, the export amounted to $\$ 5.8$ billion US $\$$ and imports 4.7 billion US\$. China is one of the main partners of Kazakhstan in trade cooperation (Satke \& Galdini, 2015). From the Chinese side trade cooperation with Kazakhstan stable increase in its volume from 432 million US\$ in the 1992 year to 10.5 billion US\$ in the 2017 year. Energy sector (oil, gas, and uranium) perspective cooperation areas in the recent time-continuous increase, synchronic trade relation (Nuryshev, 2019). It is worth mentioning the increase in Kazakhstan export and Chinese import. On the general trend of recent years both countries increasing interest in trade. The recession between 2014-2016 years reflects global crises. Occurring simultaneous recessions are related to the political change of trade relations and financial crisis in Kazakhstan.

\section{Methodology}

The study's purpose is to find out trade composition at the industrial level, to determine balance and trade performance of bilateral trade, and provide a wider understanding of trading before and during a particular time. Authors believe that it helps to improve analysis of the first stage of project OBOR, the effective- 
ness of the project in trade relations. To investigate the gap of intensity and extensity bilateral trade positions of Kazakhstan and China in both markets, first of all, used the Hummels-Klenow indices for export margins of trade developed by (Hummels \& Klenow, 2005). Also in the framework of this research will be applied analysis of the intra-industry trade activities of Kazakhstan and China, developed by (Grubel \& Lloyd, 1975). This index is chosen to assess the relationship at the intra-industry level, which helps to examine the impact of integration processes on the development of intra-industry trade between Kazakhstan and China.

\subsection{The Grubel-Lloyd Intra-Industry Trade Index}

Grubel \& Lloyd $(1971,1975)$ intra-industry trade index is one of the main quantitative analysis tools, reveals the degree of trading power of one single industry. By the research revealed types of intra-industry trade, both different types giving a different explanation. In horizontal intra-industry trade based on product differentiation, when export and import of the same category groups are defined in the same processing level. In vertical intra-industry trade export and import of product of the same category but in a different level of processing. Within the framework of the given research, the interpretation of intra-branch trade will be used, as trade relations between the same product group of Kazakhstan and China, from both side economies. First of all, to compute the Grubel-Lloyd intra-industry trade index is to choose the main product goods category in the bilateral trade data. For this analysis selected 11 categories of product (consumer goods, intermediate goods, and raw materials, chemicals, food product, fuels, hide and skins, metals, minerals, textiles, and clothing, and vegetables). This analysis calculates the degree of intra-industry trade between Kazakhstan and China in their trading partner relationship and vice versa. This analysis uses the adjusted Grubel-Lloyd intra-industry trade index, defined in Equation (1).

$$
I I T_{k}=1-\frac{\sum_{i}\left|X_{i k}-M_{i k}\right|}{\sum_{i}\left(X_{i k}-M_{i k}\right)}
$$

where, $X_{i k}$ is country is export of product or industry $k, M_{i k}$ is country is import of product or industry $k$. Value is between 0 and 1 . If it equals 1 , then the intra-industry trade of Kazakhstan and China is complete; in the case where the Grubel-Lloyd index equals 0 , there is only industry export or industry import. In the case when one country just exports particular goods within the same category of goods, intra-industry trade will be absent.

\subsection{The Hummels-Klenow Indices for Export Margins of Trade}

Based on the empirical researches developed by (Feenstra, 1994; Hummels \& Klenow, 2005), the export share of the country decomposed to extensive and intensive margins. That brought measures for the management of products exported by the country. The main values of extensive and intensive margins of 
trade are highlighted as; the extensive margin measures the degree of diversity of different products, while the intensive margin measures the intensity of export for the selected product.

Following the methods adapted to geographical markets developed by (Hummels \& Klenow, 2005), analyze export margins indices for both countries Kazakhstan and China during the years 2002-2017. In this research, intensive margins are Kazakhstan's market share in the destination country China and other vises. Extensive margins of trade are the share of China destination markets in world trade, and the same for Kazakhstan side, represented in Equations (2) and Equations (3).

$$
\begin{gathered}
I M^{i}=\frac{\sum_{d \in G_{1}^{i}} x_{d}^{i}}{\sum_{d \in G_{1}^{i}} x_{d}^{w}} \\
X M^{i}=\frac{\sum_{d \in G_{1}^{i}} x_{d}^{w}}{\sum_{d=1}^{m} x_{d}^{w}}
\end{gathered}
$$

where, $i$ s destination markets in world trade; let

$G_{1}^{i}$ be the set of destination markets where $i$ exports; $x_{d}^{1}$ be the dollar value of $i$ s total exports of good $d ; x_{d}^{w}$ be the dollar value of world exports of good $d$.

Positive country export to total national exports of the country, in both margins, equals to any numerical value between 0 and 1 . Either by (Hummels \& Klenow, 2005) was constructed, the overall share of the country market exports to another country or region, applied by Equation (4).

$$
T M^{i}=X M^{i} * I M^{i}=\frac{\sum_{d \in G_{1}^{i}} x_{d}^{i}}{\sum_{d=1} x_{d}^{w}}
$$

\section{An Empirical Analysis and Result}

Empirical analysis characterizes two-sided relations in the chosen poles of influence as a positive factor of trade relations. This supports the development of the basic theory (Heckscher \& Ohlin, 1933). Under the aegis of the consideration of relations between China and Kazakhstan, other aspects of the theory influencing the efficiency of trade export and import in the international arena were lowered. Selected period 2002-2017 years, the database is a statistical statement of World Bank, complemented by Ministry of National Economy of the Republic of Kazakhstan Statistics committee. In the works (Amurgo-Pacheco \& Pierola, 2008; Feenstra, 2008; Helpman, Melitz, \& Rubinstein, 2008; Hummels \& Klenow, 2005) the same analysis was applied for the estimation of the relationship model and the influence of intensive and extensive trade margins. The above analysis took into account the distance between the traded countries and the factor of the size of the market and the economies of the countries. These factors were not involved in IIT and export margins analysis; the reason is the consideration of bilateral development of trade, and not comparing its trade-economic force with the trading countries. Speaking about the significance of economic 
development and the size of the market of developing countries allows analyzing data with the account of privileged criteria in the direction of China. This is important in calculating the results, as one of the postulates read as follows, bigger countries are exporting bigger and not only in volume but also in greater diversity.

In this article, the presentation collected data for 15 years and analyzed the relationship between trade indicators. These figures are compared to the stated criteria for improving economic indicators. One of which is the comparison of the declared categories of trade goods in the project. In this case, the amplitude of the impact of greater demand for these goods increases, which confirms the increase in the efficiency of the relationship. On the other hand, it may be the material for the study of the project as a whole.

\subsection{The Grubel-Lloyd Intra-Industry Trade Analysis}

After the entire period of time covered in this work, there is a tendency to strengthen the IIT trade between Kazakhstan and China, so in the categories of raw materials, food products, fuels, and minerals (desire for 0 ), that takes a turn for the complete specialization. Also in Table 1, there is an opposite value of the intermediate goods, chemical, and vegetables category.

At the same time, Kazakhstan's indicators are trying to leave the borders, but the overall picture remains positive criteria of development and full specialization in most areas. We will apply a detailed overview in Figure 1 of such areas as (raw material, fuels, minerals, and food products).

Table 1. Export decomposition of intra-industry trade and trade margins, Kazakhstan and China, 2002-2017 years.

\begin{tabular}{ccccccc}
\hline & IIT China & IM China & XM China & ITT Kazakhstan & IM Kazakhstan & XM Kazakhstan \\
\hline 2002 & 0.450217 & 0.064996 & 0.026792 & 0.246683 & 0.003652 & 0.026797 \\
2003 & 0.489127 & 0.070624 & 0.032330 & 0.266458 & 0.004439 & 0.032339 \\
2004 & 0.488749 & 0.075759 & 0.040313 & 0.327949 & 0.005445 & 0.040324 \\
2005 & 0.471896 & 0.084701 & 0.048202 & 0.326809 & 0.005871 & 0.048216 \\
2006 & 0.483336 & 0.090934 & 0.059411 & 0.322087 & 0.006313 & 0.059435 \\
2007 & 0.495634 & 0.096439 & 0.073375 & 0.341643 & 0.007262 & 0.073407 \\
2008 & 0.524740 & 0.101096 & 0.094052 & 0.395501 & 0.008679 & 0.094093 \\
2009 & 0.564331 & 0.102703 & 0.080670 & 0.273443 & 0.007785 & 0.080718 \\
2010 & 0.566717 & 0.110706 & 0.110292 & 0.267302 & 0.007142 & 0.110373 \\
2011 & 0.548899 & 0.114475 & 0.153866 & 0.229730 & 0.008622 & 0.154066 \\
2012 & 0.592605 & 0.119905 & 0.179781 & 0.236749 & 0.009311 & 0.180042 \\
2013 & 0.581297 & 0.122532 & 0.229531 & 0.269518 & 0.007625 & 0.229694 \\
2014 & 0.578104 & 0.130130 & 0.291449 & 0.282957 & 0.007383 & 0.291580 \\
2015 & 0.520119 & 0.136410 & 0.340449 & 0.310943 & 0.005919 & 0.340512 \\
2016 & 0.457699 & 0.133820 & 0.490259 & 0.325280 & 0.005299 & 0.490246 \\
2017 & 0.362714 & 0.139754 & 0.565213 & 0.334866 & 0.006960 & 0.534972 \\
\hline
\end{tabular}




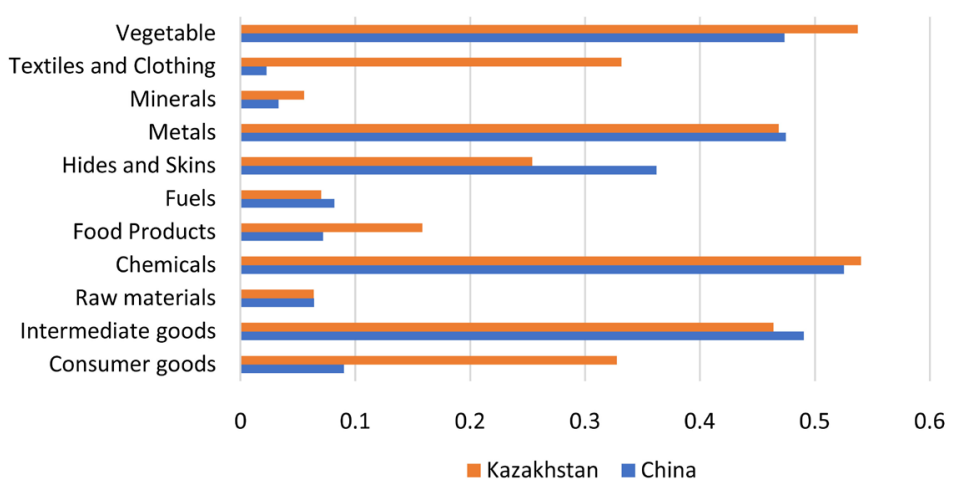

Figure 1. China $(\mathrm{CN})$ \& Kazakhstan $(\mathrm{KZ})$ intra industry trade flows, raw materials, food products, fuels, minerals, 2002-2017years.

The analysis of these categories shows a steady increase in the high IIT in the commodity sectors. Manufacture production cannot be equated with raw materials according to the data of recent years. Approximation to the full specialization of these products found in the area of 2010. With regard to the situation last 5 years, raw materials and food product are moving to the values of IIT in these areas, the remaining two categories (minerals and fuels) be categorized as almost complete IIT.

The main categories of high-level IIT are established in Table 1 which means aspiration to full IIT of all trade, to the low level of IIT in turn of a group of products only used in IIT.

The collected data solves the problem of the IIT analysis; first, we stand out 3 (2002, 2014, 2017 years) presented in Figures 2-4 for comparison of the period of IIT. The selection of these years timed to the OBOR project and the criteria for the overall evaluation of bilateral trade. So the selected year's trade composition changed to 2002 the strongest ties of the IIT between Kazakhstan and China were textile and clothing, minerals, fuels, food products, raw materials. At the end of the decade fuels, minerals and clothing approached the complete IIT, the distance from the complete merger are vegetables, metal, and intermediate goods. The last period is considered to be 2017, the decline occurs in high-level IIT such as raw material and clothing. It is worth noting that the category of consumer goods retains its position for the duration of the entire research period, this product group is in the group of high IIT.

\subsection{The Hummels-Klenow Analysis for Export Margins of Trade}

Findings in research works (Feenstra, 1994; Hummels \& Klenow, 2005), narrates about the understanding of extensive export margins as getting each market category equal to its share in the world's exports of this category. A country with a higher intensive export margin and lower extensive export margin, concentrate exports in small quantity markets. In our case opposite comparison result, intensive export margin lower and the extensive margin higher that means the country coordinates its market in various categories, exported to a greater number of markets. 


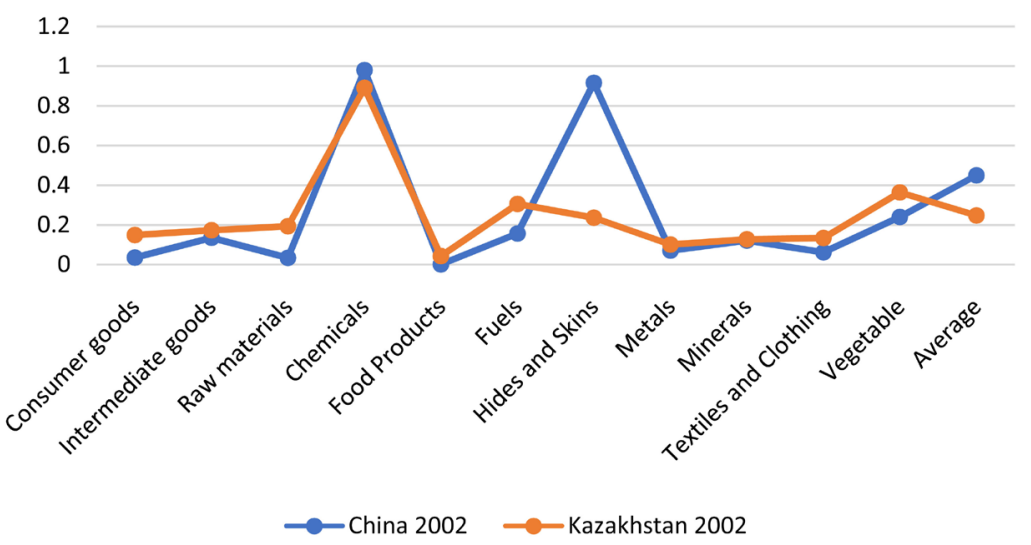

Figure 2. China (CN) \& Kazakhstan (KZ) intra industry trade flows, in product categories, 2002 year.

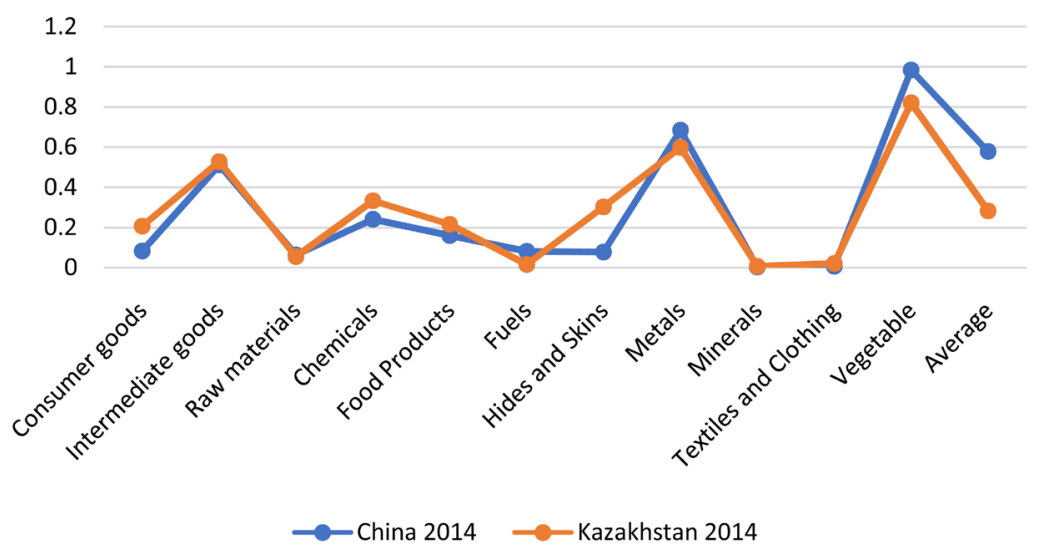

Figure 3. China $(\mathrm{CN})$ \& Kazakhstan $(\mathrm{KZ})$ intra industry trade flows, in product categories, 2014 year.

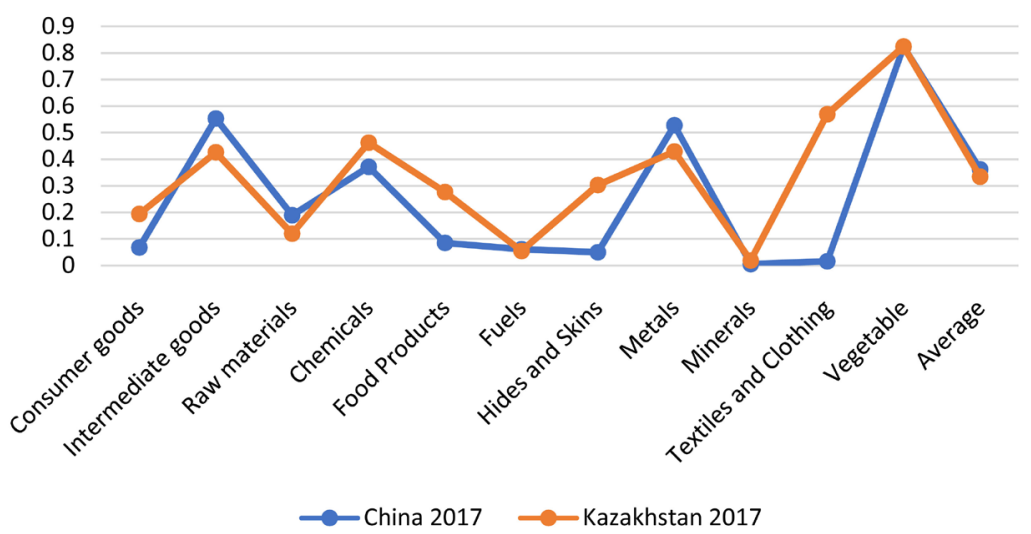

Figure 4. China $(\mathrm{CN})$ \& Kazakhstan (KZ) intra industry trade flows, in product categories, 2017 year.

For consideration, the influence of the bilateral relationship margin again allocated to the period category (2003-2011; 2011-2017 years). So Table 1 in 2002, Chinese intensive margins (0.064996) and extensive (0.026792) were that gives acceptable indicators for those years. The breadth of the presence of the Chinese 
market in the territory of Kazakhstan was also determined by the Kazakh side in the elected categories took place the main reflection of the exported goods. Slow growth by intensive margin was revealed in Kazakhstan in 2002 and takes his position until today. In Table 2 during the time period from 2003 to 2013, China's intensive margin had high annual average gains in 2003 (8.7\%) and 2005 (11.8\%), the total increase of this period was $9.42 \%$. The growth of Kazakhstan's intensive margin at the beginning of this period, in 2003 (21.5\%) and 2004 (22.7\%), the average annual growth was high. As for 2011, the increase was by $20.7 \%$ that's given a new potential in the development of the intensity of trade turnover. The extensive margin developed gradually with the growth of potential from both trading parties. The average annual growth was China (22.43\%) Kazakhstan $(22.45 \%)$ is the high degree of diversity of different products in bilateral trade. In Table 3 second period from 2011 to 2017 years, a positive growth of Kazakhstan (25.8\%) and China's (26.7\%) extensive margin, the largest increase was seen in 2016 with growth indicators $44 \%$. Data of the period since the beginning of the OBOR stable volume growth in trading categories. As for the intentional side, a positive increase is observed from China, the intensity of trading products returned by $3.4 \%$ for the entire period, in 2014 the increase compared to the previous period was $6.2 \%$ and increase until the end of the period. Kazakh side performed as a shortage of trading volume, the intensity of trade turnover with China has returned by only $1.2 \%$ for the two-day period. There is a positive excerpt in 2017, the intensity increased by $31.3 \%$. Figure 5 showing the overall picture comparison of the period before the project and during the first years of the OBOR project, only the intensity of Kazakhstan trade has a negative value and is a decrease in growth by $-0.5 \%$. In turn, other indicators of growth for 2014-2017 years also lag behind the previous period in the difference of $0.7 \%$ $2.4 \%$.

Table 2. The average percentage (\%) of the intensive (IM) and extensive (XM) margins of trade, China and Kazakhstan, 2003-2011 years.

\begin{tabular}{cccccccccc}
\hline & IM China & $\%$ & XM China & $\%$ & IM Kazakhstan & $\%$ & XM Kazakhstan & $\%$ \\
\hline 2003 & 0.070624056 & $8.7 \%$ & 0.032329803 & $20.7 \%$ & 0.004438859 & $21.5 \%$ & 0.032339108 & $20.7 \%$ \\
2004 & 0.075759287 & $7.3 \%$ & 0.040312832 & $24.7 \%$ & 0.005445076 & $22.7 \%$ & 0.040324311 & $24.7 \%$ \\
2005 & 0.084700949 & $11.8 \%$ & 0.048201736 & $19.6 \%$ & 0.005870905 & $7.8 \%$ & 0.048216117 & $19.6 \%$ \\
2006 & 0.090933597 & $7.4 \%$ & 0.059411099 & $23.3 \%$ & 0.006312987 & $7.5 \%$ & 0.059435263 & $23.3 \%$ \\
2007 & 0.096438673 & $6.1 \%$ & 0.073375104 & $23.5 \%$ & 0.00726213 & $15.0 \%$ & 0.073407247 & $23.5 \%$ \\
2008 & 0.101095974 & $4.8 \%$ & 0.09405169 & $28.2 \%$ & 0.008678884 & $19.5 \%$ & 0.094093026 & $28.2 \%$ \\
2009 & 0.102702884 & $1.6 \%$ & 0.080670441 & $-14.2 \%$ & 0.007784706 & $-10.3 \%$ & 0.080717525 & $-14.2 \%$ \\
2010 & 0.110705518 & $7.8 \%$ & 0.110291937 & $36.7 \%$ & 0.007141515 & $-8.3 \%$ & 0.110372714 & $36.7 \%$ \\
2011 & 0.114474878 & $3.4 \%$ & 0.153865831 & $39.5 \%$ & 0.00862191 & $20.7 \%$ & 0.15406628 & $39.6 \%$ \\
$\%$ & $9.42 \%$ & $6.53 \%$ & $7.69 \%$ & $22.43 \%$ & $0.68 \%$ & $10.70 \%$ & $7.70 \%$ & $22.45 \%$ \\
\hline
\end{tabular}




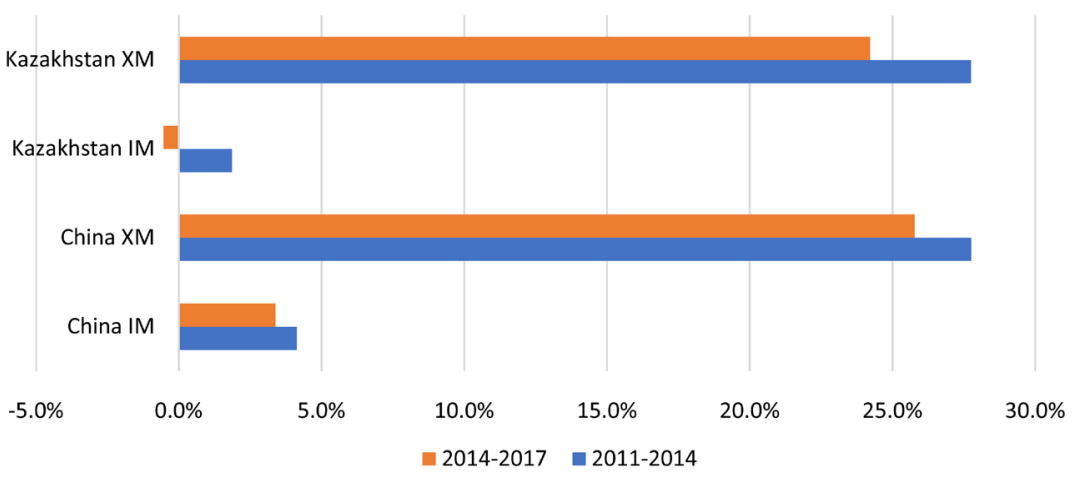

Figure 5. Comparison margins of export during the periods 2011-2014; 2014-2017 years.

Table 3. The average percentage (\%) of the intensive (IM) and extensive (XM) margins of trade, China and Kazakhstan, 2011-2017 years.

\begin{tabular}{ccccccccc}
\hline & IM China & $\%$ & XM China & $\%$ & IM Kazakhstan & $\%$ & XM Kazakhstan & $\%$ \\
\hline 2011 & 0.114475 & $3.4 \%$ & 0.153866 & $39.5 \%$ & 0.008622 & $20.7 \%$ & 0.154066 & $36.6 \%$ \\
2012 & 0.119905 & $4.7 \%$ & 0.179781 & $16.8 \%$ & 0.009311 & $8.0 \%$ & 0.180042 & $16.9 \%$ \\
2013 & 0.122532 & $2.2 \%$ & 0.229531 & $27.7 \%$ & 0.007625 & $-18.1 \%$ & 0.229694 & $27.6 \%$ \\
2014 & 0.130130 & $6.2 \%$ & 0.291449 & $27.0 \%$ & 0.007383 & $-3.2 \%$ & 0.291580 & $26.9 \%$ \\
2015 & 0.130130 & $4.8 \%$ & 0.340449 & $16.8 \%$ & 0.005919 & $-19.8 \%$ & 0.340512 & $16.8 \%$ \\
2016 & 0.133820 & $1.9 \%$ & 0.490259 & $44.0 \%$ & 0.005299 & $-10.5 \%$ & 0.490246 & $44.0 \%$ \\
2017 & 0.139754 & $4.4 \%$ & 0.490259 & $15.3 \%$ & 0.006960 & $31.3 \%$ & 0.490246 & $9.1 \%$ \\
$\%$ & $12.8 \%$ & $3.4 \%$ & $32.2 \%$ & $26.7 \%$ & $0.7 \%$ & $1.2 \%$ & $31.7 \%$ & $25.8 \%$ \\
\hline
\end{tabular}

\section{Conclusion}

Kazakhstan and China have been in economic relations since the formation of Kazakhstan as an independent state. After years of cooperation, countries have managed to increase trade. Trade has mostly always focused on privileged categories of goods related to the geographical surplus from Kazakhstan and production capacity from China. This uneven distribution has led to unbalanced trade relations. That for the most part did not interfere with economic growth, but gradually there is a need to change trade relations to more profitable. This is due to the growing interest of countries in more profitable cooperation and agreement. Therefore, the emergence of the OBOR project has prompted the development of its personal strategies to improve the work of the economic union. For its part, Kazakhstan joined the project and took a geographically important position in it. Returning to not quite balanced trade relations, it was worth paying attention to how these relations will change with the development of the OBOR project.

Answering the question of how to realize the potential of the OBOR in the macroeconomy, empirical analysis of the IIT index is represented as partially balanced. To a greater extent, IIT trade is developing in the commodity industries sectors, the energy sector (oil, gas, and uranium) is promising areas of co- 
operation in recent years. Accordingly, the categories (minerals and fuels) are classified as almost fully balanced IIT. This confirms the growing interest in the trade sectors represented in the draft OBOR. Further development of the project involves the development of other sectors of trade. The development of the project is confirmed by a numerical increase in interest in the categories stated in the project.

Empirical analysis considering the increase in the export intensity of trade in large volumes in product categories, China performance analyzed as intensive in the main elected categories presented the intensity of Kazakhstan in supplies to China reaches a loyal level in raw material, metal, mineral. The development of extensive trade flows between Kazakhstan and China is characterized as a stable chronicled relationship. In the bilateral trade market, these countries emphasize the full extensity of flows, which characterizes their trade flows as trade in a larger number of goods. Comparing 2 periods of time (2011-2014; 2014-2017) the period of time at the initial stage of OBOR is characterized by a decrease in the percentage of the extensiveness of flows. Improving product diversity will increase the key indicators of inter-industry trade efficiency. As the study showed, the increase in turnover of the same product categories does not significantly affect the indicators of bilateral trade between Kazakhstan and China which suggests developing potential for greater variation in product categories in bilateral relationships. The results of this study reveal the need for diversity in trade elements. It should be assumed that Kazakhstan needs to introduce exports of manufactured products and equate it with resource export. In this case, both trade margin indicators will be equated to the coefficients of Chinese exports to Kazakhstan.

\section{Acknowledgements}

I express my great gratitude to Hohai University Professors as my teacher and mentors, in the direction of this project. I'm grateful to all of those I had the pleasure to work with during this time, especially the research team of Business School and Innovative Team of Philosophy and Social Science in Jiangsu in the ongoing research collaboration and support. This research project would not be complete without the constant cooperation of the above-mentioned researchers, also I would like to highlight and bring my gratitude to Dr. He Zhengqi for his help.

\section{Conflicts of Interest}

The authors declare no conflicts of interest regarding the publication of this paper.

\section{References}

Allayarov, P. A., \& Li, B. (2017). An Empirical Analysis of Bilateral Trade Relations between Kazakhstan and China. International Journal of Economics, Commerce and Management, 5, 260-273. http://ijecm.co.uk 
Amurgo-Pacheco, A., \& Pierola, M. D. (2008). Patterns of Export Diversification in Developing Countries: Intensive and Extensive Margins (pp. 1-34). Policy Research Working Paper No. 4473, Washington DC: World Bank.

https://openknowledge.worldbank.org/handle/10986/6447 https://doi.org/10.1596/1813-9450-4473

Coughlin, C. C. (2012). Extensive and Intensive Trade Margins: A State-by-State View. Issue Working Paper 2012-002A, St. Louis, MO: Federal Reserve Bank of St. Louis.

http://research.stlouisfed.org/wp/2012/2012-002.pdf

https://doi.org/10.20955/wp.2012.002

Crozet, M., \& Koenig, P. (2010). Structural Gravity Equations with Intensive and Extensive Margins. Canadian Journal of Economics, 43, 41-62. https://doi.org/10.1111/j.1540-5982.2009.01563.x

Dodonov, V. (2010). Kazakhstan and China: Trade and Economic Cooperation. China and Eurasia Forum Quarterly, 8, 11-15.

https://www.academia.edu/8965467/Kazakhstan_and_China_Trade_and_Economic_C ooperation

Evenett, S. J., \& Venables, A. J. (2002). Export Growth by Developing Countries: Market Entry and Bilateral Trade Flows. Research Platform Alexandria. https://www.alexandria.unisg.ch/publications/22177

Feenstra, R. C. (1994). New Product Varieties and the Measurement of International Prices. American Economic Review, 84, 157-177.

http://links.jstor.org/sici?sici=0002-8282\%28199403\%2984\%3A1\%3C157\%3ANPVAT $\mathrm{M} \% 3 \mathrm{E} 2.0 . \mathrm{CO} \% 3 \mathrm{~B} 2-\mathrm{E} \&$ origin=repec

Feenstra, R. C. (2008). Terms of Trade and the Measurement of Real GDP 1995 (pp. 1-41).

Giri, R. (2007). The Heckscher-Ohlin Model.

http://ciep.itam.mx/ rahul.giri/uploads/1/1/3/6/113608/ho_model.pdf

Grubel, H., \& Lloyd, P. J. (1971). The Empirical Measurement of Intra-Industry Trade. Economic Record, 47, 494-517. https://doi.org/10.1111/j.1475-4932.1971.tb00772.x

Grubel, J. H., \& Lloyd, P. J. (1975). Intra-Industry Trade: The Theory and Measurement of International Trade in Differentiated Products. Journal of International Economics, 6, 312-314. http://www.sciencedirect.com/science/article/pii/0022-1996(76)90008-8 https://doi.org/10.1016/0022-1996(76)90008-8

Haveman, J., \& Hummels, D. (2004). Alternative Hypotheses and the Volume of Trade: The Gravity Equation and the Extent of Specialization. Canadian Journal of Economics, 37, 199-218. https://doi.org/10.1111/j.0008-4085.2004.011_1.x

Heckscher, E., \& Ohlin, B. (1933). International and Inter-Regional Trade. Cambridge: Harvard University Press.

https://www.abebooks.com/first-edition/Interregional-International-Trade-OHLIN-Be rtil-Cambridge/372604098/bd

Helpman, E., Melitz, M., \& Rubinstein, Y. (2008). Estimating Trade Flows: Trading Partners and Trading Volumes. The Quarterly Journal of Economics, 123, 441-487.

https://academic.oup.com/qje/article-abstract/123/2/441/1930829?redirectedFrom=full text\#

https://doi.org/10.1162/qjec.2008.123.2.441

Hummels, D., \& Klenow, P. J. (2005). The Variety and Quality of a Nation's Exports. American Economic Review, 95, 704-723. https://doi.org/10.1257/0002828054201396

JSC Samruk-Kazyna (2017). One Belt \& One Road Leveraging Infrastructure Value Potential. https://sk.kz/upload/iblock/71e/71e9051a57a5b2e474c883a4f4de5a15.pdf

Kehoe, T. J., \& Ruhl, K. J. (2013). How Important Is the New Goods Margin in Interna- 
tional Trade? Journal of Political Economy, 121, 358-392.

https://doi.org/10.1086/670272

Kim, T., \& Meng, D. (2015). Dynamic Changes of China's Export Specialization. Modern Economy, 6, 633-641. https://doi.org/10.4236/me.2015.65060

Kojima, K. (1964). The Pattern of International Trade among Advanced Countries. Hitotsubashi Journal of Economics, 5, 16-36.

http://hermes-ir.lib.hit-u.ac.jp/rs/bitstream/10086/8091/1/HJeco0050100160.pdf

Li, Y., \& Edmonds, C. (2010). China's Bilateral Trade Intensity. Proceedings of the International Conference on E-Business and E-Government, ICEE 2010, Guangzhou, 7-9 May 2010, 5110-5113. https://doi.org/10.1109/ICEE.2010.1282

Nuryshev, S. (2019). Kazakhstan and China: Strategic Partnership and Good-Neighborliness. The Ministry of Foreign Affairs Republic of Kazakhstan. https://www.silkroute.news/article/801211/

OECD (2018). China's Belt and Road Initiative in the Global Trade, Investment and Finance Landscape (pp. 61-101). OECD Business and Finance Outlook 2018, Paris: OECD Publishing. https://doi.org/10.1787/bus_fin_out-2018-6-en

Pak, E. V. (2018). The Role of International Intra-Industry Trade in Deepening Integration in the Eurasian Economic Union. Russian Foreign Economic Journal, 5, 95-104. http://www.rfej.ru/rvv/id/D00475FD9

Prusa, T. J., \& Besedes, T. (2011). The Role of Extensive and Intensive Margins and Export Growth. Journal of Development Economics, 96, 317-379.

https://doi.org/10.1016/j.jdeveco.2010.08.013

Satke, R., \& Galdini, F. (2015). Between East and West: Kazakhstan's Development along China's New Silk Road. Revista CIDOB d'Afers Internacionals, 110, 87-112. http://www.osce-academy.net/upload/file/Between_East_and_West.pdf

Shelburne, R. C., \& Pidufina, O. (2006). Evolving Trade Patterns in the CIS: The Role of Manufacturing. International Trade and Finance Association Conference Papers No. 1078, 1-118. https://econpapers.repec.org/RePEc:bep:itfapp:1078 https://doi.org/10.2139/ssrn.2282393

Simone, B.-R. (2015). China and Kazakhstan: Economic Hierarchy, Dependency and Political Power? Department of International Relations of the London School of Economics. http://etheses.lse.ac.uk/3126/1/Bohnenberger-Rich_Kazakhstan_and_China.pdf

Sun, L. (2012). Analysis on Economic and Trade Relations between China and Kazakhstan. The Journal of Economic Research \& Business Administration, 94, 58-62. https://be.kaznu.kz/index.php/math/article/view/290

Widodo, T. (2009). Modified Grubel-Lloyd Index: Intra-Industry Trade and Intra-Regional Trade in East Asia. Munich Personal RePEc Archive 7068. https://mpra.ub.uni-muenchen.de/id/eprint/77992

Zhang, W., Wu, Q., \& Shi, H. (2017). Study on Trade Complementarity and Trade Potential between China and Kazakhstan in the Background of "One Belt and One Road". International Journal of Science and Research, 6, 116-128. 